\title{
EFFECT OF HEAD TEACHERS' COLlabORATIVE PARTNERSHIPS ON INCLUSIVE EDUCATION IMPLEMENTATION IN PUBLIC PRIMARY SCHOOL
}

\author{
Douglas Shiwani* \\ University of Nairobi, Kenya \\ E-mail:shiwanisigi@gmail.com
}

\section{Winston Akala}

University of Nairobi, Kenya

E-mail: akalajumba@yahoo.command

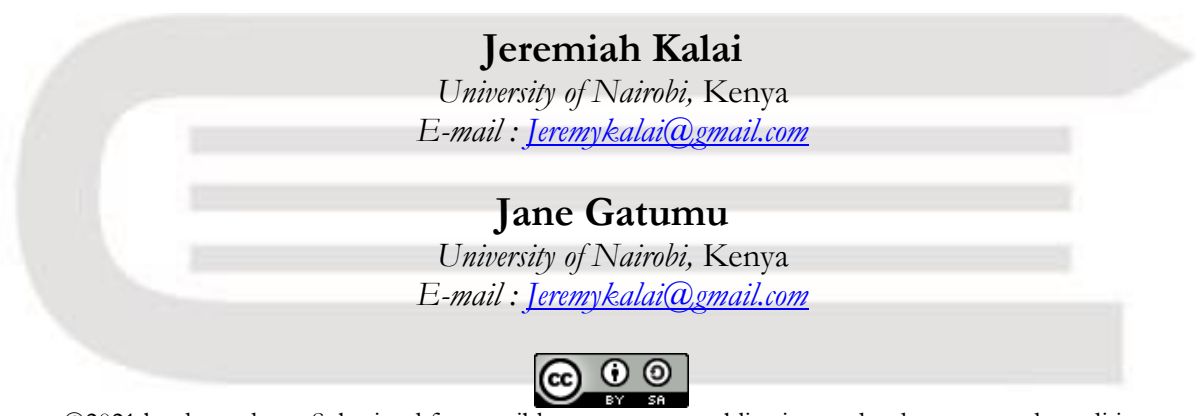

(C)2021 by the authors. Submitted for possible open access publication under the terms and conditions of the Creative Commons Attribution-ShareAlike 4.0 International License (CC-BY-SA) license (https://creativecommons.org/licenses/by-sa/4.0/) doi DOI : http:// dx.doi.org/10.30983/educative.v6i1.4289. *Corresponding author

\section{Abstract}

The purpose of the study was to investigate the effect of head teachers' collaborative partnerships with parents, government agencies and NGOs, on the implementation of inclusive education in public primary schools in Nairobi City County in Kenya. Descriptive survey was applied, and Chi-square tested the null hypothesis. Questionnaires were administered to 71 head teachers and 297 teachers, supplemented by document analysis. Interview was used on eight Quality Assurance Standards Officers (QASOs) and four Education Assessment Resource Centre Officers (EARCs). Quantitative data was coded and analysed using descriptive statistics, and presented in frequency tables and bar graphs. Qualitative data was coded, transcribed and presented in narrative form. The study established the relationship between head teachers' collaborative partnerships with implementation of inclusive education. Nevertheless, majority of schools lacked well- structured coordinated partnerships resulting in low participation in schools programs as referenced by head teachers and teachers on provision for specialized teaching and learning resources, $63.4 \%$ and $63.3 \%$; assessment of learners, $64.8 \%$ and $70.4 \%$; outsourcing of funds, $69 \%$ and $69.7 \%$. Therefore, head teachers should increase capacities in collaborative partnerships and fully utilize them for inclusive education implementation.

Keywords : content, formatting, article, partnerships collaboration, inclusive education.

\begin{abstract}
Abstrak
Penelitian ini bertujuan untuk mengetabui pengarub kemitraan kolaboratif kepala sekolab dengan orang tua, lembaga pemerintah dan LSM, pada pelaksanaan pendidikan inklusif di sekolah dasar negeri di Kota Nairobi di Kenya. Survei deskriptif diterapkan, dan Chi-square menguji hipotesis nol. Kuesioner diberikan kepada 71 kepala sekolah dan 297 guru, dilengkapi dengan analisis dokumen. Wawancara digunakan pada delapan Petugas Standar Penjaminan Mutu (QASO) dan empat Petugas Pusat Penilaian Pendidikan (EARC). Data kuantitatif diberi kode dan dianalisis menggunakan statistik deskriptif, dan disajikan dalam tabel frekuensi dan grafik batang. Data kualitatif dikodekan, ditranskripsikan dan disajikan dalam bentuk naratif. Studi ini menjelaskan bubungan antara kemitraan kolaboratif kepala sekolah dengan implementasi pendidikan inklusif. Namun, sebagian besar sekolah tidak memiliki kemitraan terkoordinasi yang terstruktur dengan baik, yang mengakibatkan rendabnya partisipasi dalam program sekolah seperti yang dirujuk oleb kepala sekolah dan guru tentang penyediaan sumber untuk belajar dan mengajar, 63,4\% dan 63,3\%; penilaian peserta didik, 64,8\% dan 70,4\%; outsourcing dana, 69\% dan 69,7\%. Oleh karena itu, kepala sekolah harus
\end{abstract}


meningkatkan kapasitas dalam kemitraan kolaboratif dan memanfaatkannya sepenubnya untuk pelaksanaan
pendidikan inklusif.

Kata kunci : konten, format, artikel, kolaborasi kemitraan, pendidikan inklusif.

\section{Introduction}

Developing countries including Kenya look upon Non-Governmental Organisations (NGOs) to take the lead in implementing inclusive education policy using resources and projects. However, these projects do not sufficiently address inclusive education for learners with special needs, and not much is known about the effects of NGOs-schools partnerships on the implementation of inclusive education [United Nation Education, Scientific and Cultural Organization] ${ }^{1}$. Disappointingly, the role of governments seem to be limited to formulation or changing of education policies; whereas, NGOs act as pressure groups for policy change, service delivery, community awareness and mapping resources. ${ }^{2}$ For instance, parents under the auspices of Nairobi Family Support Services (NFSS) resorted to joint advocacy for their children's educational rights, in the case of very few learners with special needs who enrolled in primary schools in Nairobi City County. ${ }^{3}$ In Kenya, there has been a decline in enrolment of these learners from $78 \%$ in 2007 to $52.3 \%$ in 2017 , attributed to failure by head teachers and stakeholders to initiate resource, infrastructural and Special Needs Education interventions in primary schools ${ }^{4} ;$. There was need for collaborative partnerships to find out what

1 UNESCO, Policy Guidelines on Inclusion in Education. (Paris, 2009).

2 J.P Meenakshi, S., Anke de Boer, and Sip, 'Inclusive Education in Developing Countries: A Closer Look at Its Implementation in the Last 10 Years.' (Umang, Jaipur India: Routeledge.TaylorandFrancisGroup., 2013).

3 Nairobi City County, Taskforce Education Report. (Nairobi, 2015).

${ }^{4}$ D. Njoka, E., Riechi, A., Obiero, C., Kemunto, E., Muraya, D., Ongoto, J. \& Amenya, Towards Inclusive and Equitable Basic Education System: Kenya's Experience (Ouagadougou, Burkina Faso, 2013). works in practice for inclusive education. ${ }^{6}$ Therefore, it was prudent to re-examine how head teachers initiate collaborative partnerships to provide educational resources and support services for implementing inclusive education.

The Convention on the Rights of Persons with Disability (CRPD) advocates for Member States to put measures including collaboration with stakeholders, accommodation and practical support services to ensure that learners with special needs access inclusive education. $^{7}$ In contrastingly, $36 \%$ of the member states have not allocated adequate finances for provision of resources, $48 \%$ do not have policies and 53\% have not initiated programs for the resources and services. ${ }^{8}$ Nongovernmental organizations do not have the financial means and capacity to develop country-wide sustainable service delivery systems [World Health Organisation]. ${ }^{9} \quad$ It demonstrates the mismatches between the policies that advocate for partnership collaboration and the inadequacies in delivery of services, that this study sought to address.

While the national governments have the primary responsibility to financing resources for inclusive education, all other related stakeholders including schools, communities, parents and service providers need to consider

${ }^{5}$ KISE, The National Survey on Children with Disabilities and Special Needs (Nairobi, 2018).

6 Department for International Development, Accessing Inclusive Education for Children with Disabilities in Kenya:Global Campaign for Education. (United Kingdom, 2015).

${ }^{7}$ CRPD, Convention on the Rights of Persons with Disabilities (New York, 2006).

${ }^{8}$ UNESCO, Education for All National Review Report: Kenya (Paris, 2015).

9 WHO, 'World Report on Disability 2011', American Journal of Physical Medicine Rehabilitation Association of Academic Physiatrists, 9.1 (2011), 549. 
acquisition, and capacity to manage the resources. ${ }^{10}$ Leithwood, Karen and Wahlstrom $^{11}$ argue that head teachers' collaborative partnerships are essential for implementing inclusive education. Barton ${ }^{12}$ postulates that schools work collaboratively with the community to provide for learners' social needs, support services and educational resources. It was of essence that this study evaluates how head teachers engage stakeholders such as parents and partnerships in provision of support services and participation in school programs to implement inclusive education in schools effectively.

However, the current major hindrances to learners with special needs access to education are the lack of recognition of specialized resources in national and institutional plans/policies, and weak stakeholder/partnership coordination in utilizing the resources. ${ }^{13}$ It is argued that parents of learners with special needs often express dissatisfaction working with school personnel and other professionals. ${ }^{14}$ Thus, the need for this study to re-examine how head teachers coordinate partnerships with their schools to implement inclusive education.

In Kenya, the National Education Sector Plan $[\mathrm{NESP}]^{15}$ allows head teachers to work collaboratively with partnerships to implement

10 WHO, CBR Guidelines. Health Component (Geneva, 2010).

${ }^{11}$ K. Leithwood, K., Seashore, K.L., Anderson, S. and Wahlstrom, Review of Research How Leadership Influences Student Learning (University of Minnesota: Wallace Foundation, 2014).

12 Paul E Barton, 'Parsing the Achievemnt Gap: Baselines for Tracking Progress', Policy Information Report, Educational Testing Service, Policy Information Center, 2003, 1-42.

13 N. Layton, 'Problems, Policies and Politics: Making the Case for Better Assistive Technology Provision in Australia.', Disability and Rehabilitation Assistive Technology, 10.3 (2015), 240-44.

14 National Council for Special Education, Literature Review of the Principles and Practices Relating to Inclusive Education for Children with Special Needs. (Europe, 2010). inclusive education. The government policy option of reducing gaps in financing of education is partnerships such as NGOs, which finance only $0.73 \%$ of education budget; nevertheless, collaboration with parents, school-communities is highly under-exploited. Gatumbi, Ayot, Kimemia and Ondigi ${ }^{16}$ study reveals that $70.7 \%$ of respondents were concerned that schools do not collaborate with the community and other agencies to support learners with special needs in schools.

It is indicated that resource allocation for Special Needs Education (SNE) was 948 million compared to 18,627 million for Free Primary Education (FPE); however, lack of specialized teachers' specialized training, teaching and learning resources hampered learners with special needs access to schools. ${ }^{17}$ Nationally, 222,700 learners with special needs of primary school going age ${ }^{18}$ and only $48.6 \%$ of these learners attended school, but 51.4\% did not. ${ }^{19}{ }^{20}$. In Nairobi City County out of 468,754 pupils who enrolled in primary schools only 1880 were special needs against the backdrop of $105,727 .{ }^{21}$ The Department for International Development ${ }^{22}$ report, and National Special Needs Education(SNE) Survey Report ${ }^{23}$ revealed that learners with special needs are denied access in primary schools due to lack of resources and specialized

15 Republic of Kenya. (2014a), National Education Sector Plan 2013-2018. (Nairobi, 2014).

16 Agnes Gathumbi and others, 'Teachers' and School Administrators' Preparedness in Handling Students with Special Needs In Inclusive Education In Kenya', Journal of Education and Practice, 6.24 (2015), 12939.

17 Republic of Kenya, Education Sector Report 2017/18-2019/20. (Nairobi, 2016).

18 KISE.(2018)

19 Republic of Kenya. (2018a), Sector Policy for Learners and Trainees with Disabilities (Nairobi, 2018).

${ }^{20}$ KISE.(2018)

${ }^{21}$ Nairobi City County.(2015)

22 Department for International Development.(2015)

${ }^{23}$ Republic of Kenya. (2014b)., National Special Needs Education Survey Report. (Nairobi, 2014). 
teachers. The Handicap International ${ }^{24}$ report indicates that head teachers have great influence on teachers and community, and need to collaborate with partnerships to provide educational resources and support services for implementing inclusive education. This demonstrates that head teachers in collaboration with partnerships were not doing all that they were expected to do to implement inclusive education, which is the onus of this study.

\section{Research Objectives}

The following research objectives were formulated to guide the study:

1. To establish head teachers' collaborative partnerships for inclusive education implementation in public primary schools in Nairobi City County of Kenya.

2. To determine the effectiveness of head teachers' collaborative partnerships on inclusive education implementation in public primary schools in Nairobi City County of Kenya.

3. To establish the relationship between head teachers' collaborative partnerships with inclusive education implementation in public primary schools in Nairobi City County of Kenya.

\section{Summary of Related Literature Review}

The development of partnerships among stakeholders supports government efforts, collaboration, and prevents duplication. ${ }^{25}$ In

${ }^{24}$ Handicap International, Inclusive Education in Kenya Assessment Report. Policy Paper on Inclusive Education in Kibera and Dandora. (Nairobi, 2013).

${ }^{25}$ WHO, 'World Report on Disability 2011'.

26 UNESCO, Education for All National Review Report: Kenya.

${ }^{27}$ Government of India, Scheme of Assistance of Assistance to Disabled Persons for Purchase/Fitting of Aids/ Appliances (ADIP Scheme) (New Delhi, 2014).

28 B Gold, Social Construction of Urban Education: New Jersey Whole School Reform and Teachers' Understanding of Social Class and Race (New York: Pace University, 2002).
Qatar, a public private partnership with schools provides specialized resources and services as well as research for inclusive education. In Sweden, the government supports a special initiative to promote the development of specialized resources through exhibitions, and touring for learners with special needs in Europe and Asia. ${ }^{26}$ The Government of India has adopted a scheme that makes specialized resources available free of charge to low earners and subsidies to average and high income earners. $^{27}$

Gold $^{28}$ opines that head teachers perceive policy initiatives differently but working with stakeholders enables interpretation of policy initiatives for implementing inclusive education. Coordinated partnerships between schools and partnerships lead to improved learning outcomes for learners with special needs (Stoner et al., 2005). ${ }^{29}$ However, Hayes and Bulat ${ }^{30}$ argue that head teachers ought to identify programs that will engage stakeholders including parents to support educational needs for learners with special needs and teachers training for successful implementation of inclusive education.

In Kenya, the Sector Policy for Learners and Trainees with Disabilities advocates for collaboration among parents, developmental partners, Faith Based Organisations (FBOs), agencies such as school heads and other stakeholders for effective service delivery. ${ }^{31}$ However, the SNE Policy Review Data Collection Report ${ }^{32}$, established duplication of

${ }^{29}$ E. P. Stoner, J. B., Bock, S. J., Thompson, J. R., Angell, M. E., Heyl, B. S., \& Crowley, 'Welcome to Our World: Parent Perceptions of Interactions between Parents of Young Children with ASD and Education Professionals', Focus on Autism and Other Developmental Disabilities, 20.1 (2005), 39-51.

$30 \mathrm{~J}$ Hayes, A.M. and Bulat, Disabilities Inclusive Education Systems and Policies Guide for Low and Middle Income Countries. (New York: RTI Press Publication, 2017).

${ }^{31}$ Republic of Kenya. (2018a).

32 Republic of Kenya.(2016). 
services arising from weak coordination mechanisms and the low capacity of Ministry of Education (MoE) officials to coordinate education providers. Irungu ${ }^{33}$ study revealed weak coordination between schools and Education Assessment Resource Centre (EARC) officers in providing support services. It is argued that Quality Assurance and Standards (QASOs) officers support head teachers in improving teaching and learning but have limited capacity to support head teachers to implement inclusive education. According to the Sector Policy for Learners and Trainees with Disabilities ${ }^{34}$, learners with special needs are denied access to inclusive education due to inability of regular schools to meet their social and educational needs, and the fact that EARCs have inadequate specialized equipment and resource persons to discharge their services effectively in schools.

The Republic of Kenya $a^{35} ;^{36}$ cited the lack of data on learners with special needs, policy operational framework, and stakeholders' engagement structures in management of specialized resources as a hindrance to implementation of inclusive education in Kenya. Estimating children's educational needs and mapping available specialized resources are a prerequisite for planning equitable services. In the absence of available data, 3-5 per cent of children in any population can be used as a baseline to calculate the number of learners who need the specialized resources and services. $^{3738}$.

A number of collaborative partnerships have been initiated in schools in Kenya, though not in well-structured and coordinated way. For

33 J.M. Irungu, 'Influence of Head Teacher Leadership Development on Implementation of Inclusive Education in Public Primary Schools in Kiambu County, Kenya' (University of Nairobi, 2014).

${ }^{34}$ Republic of Kenya. (2018a).

${ }^{35}$ Republic of Kenya. (2014b).

${ }^{36}$ Republic of Kenya.(2016)

${ }^{37}$ J Borg, The State of the World's Children 2013 Children with Disabilities. (New York, 2013). instance, Leonard Cheshire Disability Organization has partnered with regular schools in Western Kenya to promote inclusive education in areas such as professional development, teaching and learning resources, technical and life skills. ${ }^{39}$ In Nairobi City County, NGOs such as Mellon Educate provide financial aid to schools to enhance inclusive education, yet head teachers do not acquire adequate resources for teaching and learning. ${ }^{40}$ According to Sessional Paper of 2018 on Reforming Education and Training for Sustainable Development ${ }^{41}$, coordination of partnerships is not only important for effective management of schools resources but also for accountability and transparency. Therefore, it was prudent to re-examine how head teachers initiate collaborative partnerships for provision of educational needs and support services for diverse learners.

\section{Significance of the study}

The study contributes to discourse on the social-economic impact of inclusive education in all educational institutions. This paradigm is anchored on international commitments such as UN Convention on the Rights of Persons with Disabilities, member states legislation, strategic plans and educational policies that incorporate the element of public-private partnerships in enhancing full implementation of inclusive education. Therefore, this study informs all stakeholders on the essentiality of utilizing effectively well-structured collaborative partnerships to fully implement inclusive education for educational outcomes of diverse learners outcomes in schools.

38 WHO, 'World Report on Disability 2011'.

${ }^{39}$ L.M. Adoyo, O.P. \& Odeny, 'Emergent Inclusive Education in Kenya: Challenges and Suggestions', . . International Journal of Research in Humanities and Social Studies, 2.6 (2015), 47-52.

${ }^{40}$ Nairobi City County.(2015).

${ }^{41}$ Republic of Kenya. (2018b), Sessional Paper on Reforming Education and Training for Sustainable Development (Nairobi, 2018). 


\section{Method}

A descriptive survey design was employed in this study. Creswell ${ }^{42}$ postulates that through this design a researcher can evaluate policy issues and programs, using questionnaires and interviews, and statistically analyze data to test research hypotheses. The target population had 4546 constituents from 203 public primary schools in Nairobi City County. The sample size was 514 respondents comprising of the nine QASOs and four EARCs officers, 102 head teachers and 400 teachers, selected using consensus and simple random, respectively.

Two sets of questionnaires were designed for head teachers and teachers, interview guides were used on QASO and EARC officers to collect data. Document analysis guides were used to cross-check the documents. The instruments return rates were $71(69.6 \%)$ and $297(74.3 \%)$ for head teachers and teachers'; eight $(88.9 \%)$ and four $(100 \%)$ for QASO and EARC officers, respectively. Babbie (1989) in Best and $\mathrm{Kahn}^{43}$ suggest that a $50 \%$ response rate is adequate, while $60 \%$ and $70 \%$ are good and very good, respectively.

Face validity was enhanced by consulting the supervisors and peers in the School of Education to review the tools on appearance, appropriateness of wording, content, and format of items. Pilot test was conducted on the instruments involving five percent of the sample size. Baker ${ }^{44}$ generally recommends between $10-20 \%$ of the sample size. However, Billingham, Whitehead and Julious ${ }^{45}$ argue that a formal sample size for pilot studies may not be necessary. Cronbach ${ }^{46}$ alpha was employed

42 J.W Creswell, Educational Research: Planning, Conducting and Evaluating Quantitative and Qualitative Research, 4th edn (London: Pearson Research, 2012).

${ }^{43}$ J. V. Best, J. W., \& Kahn, Research in Education, 10th edn (Upper Saddle River, NJ: Pearson Education, Inc., 2006).

${ }^{44}$ T.I Baker, Doing Social Research, 2nd edn (New York: McGraw, 1994). to test the reliability of the instruments. The following reliability indexes were met: head teachers questionnaires, 0.876 and 0.926; teachers' questionnaires, 0.900 and 0.934; QASOs and EARCs interview guides, 1.00 and 1.000; document analysis guide, 0.945 and 0.960. Quantitative data was coded, analyzed using descriptive statistics, and presented in frequency tables and graphs. Qualitative data was coded, analyzed in themes, and presented in narrative form. Both quantitative and qualitative data findings were discussed in juxtaposition with confirming or refuting the research evidence, and reinforcing the interpretation.

\section{Findings}

\section{Head teachers' collaborative} partnerships for implementing inclusive education in schools

The responses of head teachers and teachers on head teachers' collaborative partnerships to implement inclusive are presented in Figure 1.

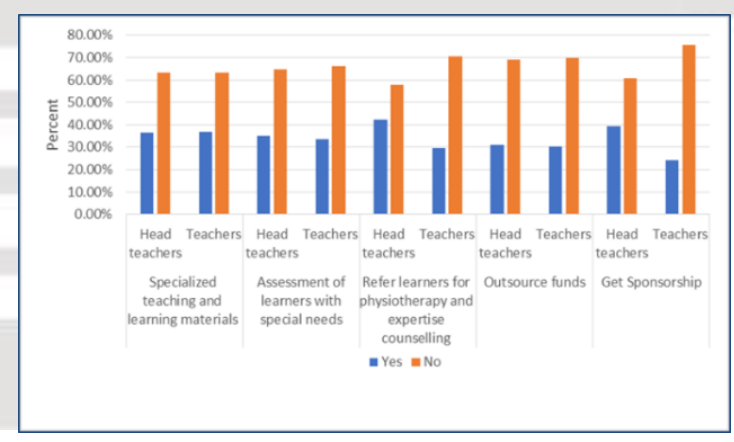

Figure 1. Responses on head teachers' partnerships collaboration for implementing inclusive education

45 Sophie Am Billingham, Amy L. Whitehead, and Steven A. Julious, 'An Audit of Sample Sizes for Pilot and Feasibility Trials Being Undertaken in the United Kingdom Registered in the United Kingdom Clinical Research Network Database', BMC Medical Research $13.1 \quad$ (2013), <https://doi.org/10.1186/1471-2288-13-104>.

46 L.R. Cronbach, Essentials of Psychological Testing, 3rd edn (New York: Harper and Row, 1970). 
Legend. $N=71 ; 297$ percentage $(\%)=$ percentage of head teachers and teachers responses on head teachers' partnerships collaboration for implementing inclusive education.

Findings in Figure 1 revealed that there were high negative scores across the following programs of school and partnerships collaboration: provision of specialized teaching and learning materials $63.4 \%$ and $63.3 \%$; assessment of learners with special needs, $64.8 \%$ and $66.3 \%$; sending learners for referred physiotherapy and expertize counseling, $57.7 \%$ and $70.4 \%$; outsourcing funds for infrastructure development, $69 \%$ and 69.7\%'; sponsorship to support school programs, $60.6 \%$ and $75.8 \%$.

\begin{tabular}{llr}
\multicolumn{1}{c}{ Effectiveness of head teachers' } \\
collaborative $\quad$ partnerships & for \\
implementing inclusive education &
\end{tabular}

Head teachers and teachers' responses on the effect of head teachers' collaborative partnerships on inclusive education implementation are displayed in Figure 2

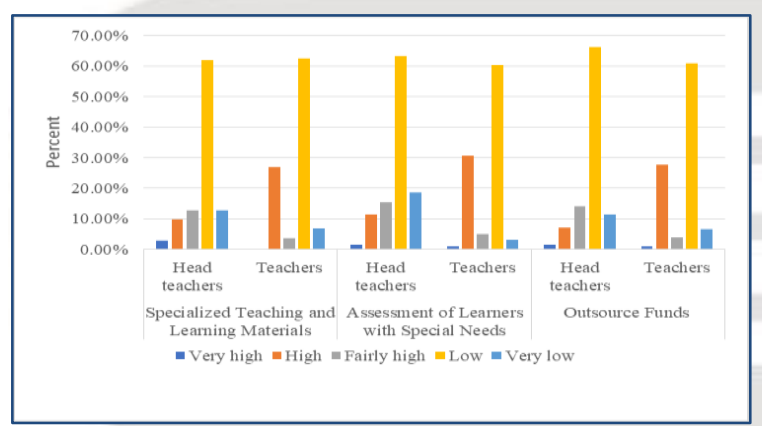

Figure 2. Responses on the effect of head teachers' partnerships on level of participation in school programs

Legend. $N=71 ; 297$ percentage $(\%)=$ percentage of head teachers and teachers responses on effect of head teachers' partnerships collaboration on level of participation in school programs.

47 J. S Duhaney, L. G. M. and Spencer, 'Parental Perceptions of Inclusive Educational Placements', Remedial and Special Education, 21.2 (2000), 121-29.
The findings in Figure 2, indicated low level of participation of partnerships in the provision of support services in their schools as illustrated: provision of specialized teaching and learning materials, $62 \%$ and $62.6 \%$ for head teachers and teachers; assessment of learners with special needs, $63.4 \%$ and $60.3 \%$; while, outsourcing of funds had $66.2 \%$ and $60.9 \%$.

\section{Discussion}

\section{Head teachers' collaborative} partnerships for implementing inclusive education in schools

The implication of the findings in Figure 1 is that there were very little, weak and unstructured collaborative efforts between the schools and the partnerships resulting in very low participation in school programs and learning outcomes for diverse learners, which dragged implementation of inclusive education. Several research indicate that both educationists and policy makers single out the challenges in collaborating schools and stakeholders in school programs, despite the crucial role they play in implementing inclusive education. $\left.{ }^{47} ;^{48}\right)$. QASO 5 was forthright:

There is no structured collaboration with partnerships. NGOs such as Ujamaa Africa, Association of Physical Disability in Kenya (APDK), and Korea International Cooperation Agency (KOICA) support infrastructure, teaching and learning resources to integrated and special schools. They come to my office to ask for directions to a school they want to visit, and I direct them.

Further analysis of the study findings on schools-partnerships collaboration in Figure 1 showed that the provision of specialized teaching and learning materials was assented by $36.6 \%$ and $36.7 \%$ head teachers and teachers.

48 J. L Epstein, School, Family and Community Partnerships: Preparing Educators and Improving Schools. (Westview: Boulder, CO, 2001). 
On the other hand, higher negative scores, $63.4 \%$ and $63.3 \%$ of the same respondents dissented it. The implication is that majority of the respondents were dissatisfied with the low collaborative efforts between schools and partnerships in provision of specialized teaching and learning materials for learners with special needs. The ramification of these findings is that there was low participation of partnerships in the provision of specialized teaching materials to schools. The document analysis of records on schools and partnerships collaboration is portrayed in Table 1.

Table 1. Records on schools collaborative partnerships for support services.

Note. $N=71 ; f=$ frequency of responses; $\%$ = percentage of responses; records available on schools partnerships collaboration for support services

\begin{tabular}{|c|c|c|c|c|c|c|}
\hline \multirow{3}{*}{$\begin{array}{l}\text { * School } \\
\text { partnerships } \\
\text { collaboration } \\
\text { for support } \\
\text { services }\end{array}$} & \multicolumn{4}{|c|}{ Evidence of records } & & \\
\hline & \multicolumn{2}{|c|}{ Available } & \multicolumn{2}{|c|}{ Unavailable } & \multicolumn{2}{|c|}{ Total } \\
\hline & $f$ & $\%$ & $f$ & $\%$ & $f$ & $\%$ \\
\hline $\begin{array}{l}\text { Specialized } \\
\text { teaching and } \\
\text { learning } \\
\text { materials }\end{array}$ & 20 & 28.2 & 51 & 71.8 & 71 & 100 \\
\hline $\begin{array}{l}\text { Assessment } \\
\text { of learners } \\
\text { with } \\
\text { Special needs }\end{array}$ & 25 & 35.2 & 46 & 64.8 & 71 & 100 \\
\hline $\begin{array}{l}\text { Outsource } \\
\text { funds for } \\
\text { infrastructure } \\
\text { and } \\
\text { school } \\
\text { programs }\end{array}$ & 19 & 26.8 & 52 & 73.2 & 71 & 100 \\
\hline
\end{tabular}

Findings on the document analysis of the sampled schools in Table 1, revealed that only $28.2 \%$ of schools had records on specialized teaching and learning materials received from

${ }^{49}$ Republic of Kenya. (2018b).

50 O. Kovač Cerović, T., Pavlović Babić, D., Jovanović, 'Foundations for Development of Monitoring Framework for Inclusive Education in Serbia.', in Monitoring Framework for Inclusive Education in Serbia, ed. by I. (Ed.) In Latinović (Belgrade: Unicef, Serbia, 2014), pp. 12-41). partners. Majority of the schools accounting for $71.8 \%$ did not keep any records to show such partnerships participation in the education of diverse learners. According to Sessional Paper of $2018^{49}$, some partnerships work directly with schools without the approval by the Ministry of Education Science and Technology leading to duplication, conflict of interests and lack of accountability. EARC 4 revealed:

Some NGOs have interest in visiting schools where they find it necessary to provide assistive devices and support services; for example, Ear Drop Foundation, Deaf Aid and APDK. I can say that we do not have much say on what goes on between the NGOs and head teachers, especially when it comes to the issue of funds. I have not seen any record on funding from sponsors.

The findings in Table 1 on document analysis and the EARC 4 verbatim resonate with a study conducted by Kovač, Pavlović, and Jovanovic ${ }^{50}$ which revealed that $60 \%$ of schools rarely initiated collaboration with the partnerships despite the partnerships willingness to provide support for teacher competencies in IEP and IE programmes. Buhere and Ochieng ${ }^{51}$ study reveal that only $37.5 \%$ (3) teachers agreed that head teachers collaborate with partners to acquire assistive devices and wheel chairs. Irungu ${ }^{52}$ study found out that only $22.4 \%$ of the resource centres were contacted by schools to provide assistive technology to learners who needed them. It was needful that head teachers re-engaged wellstructured collaborative partnerships for provision of specialized teaching and learning materials to improve access and participation in education for diverse learners.

51 Pamela Buhere and Pamela Ochieng, 'Usage of Selected Resources for Inclusive Education in Mainstream Primary Schools: Issues and Challenges From a Kenyan Perspective.', Problems of Management in the 21st Century, 8 (2013), 16-24.

52 Irungu.(2014) 
The findings from Figure 1 on assessment of learners with special needs indicate that $35.2 \%$ and $33.7 \%$ of head teachers and teachers consent that their schools made arrangements for learners' identification and assessment; however, majority representing $64.8 \%$ and $66.3 \%$ held a contrary view. This contradiction suggests that majority of the schools did not conduct identification and assessment of learners with special needs prior to admission, except for few integrated and special schools. The implication is that learners with special needs were denied access to regular schooling due to lack of expertize skills to identify and assess the learners, and inadequate facilities. Similarly, Hayes and Bulat ${ }^{53}$ study reveal that most low and middle-income countries do not have systems in place to identify learners with special needs as they rarely administer vision and hearing assessments in primary schools. In Kenya half of learners in special units and fifth in special schools country wide were not assessed prior to admission. ${ }^{54}$ Juma and Malasi ${ }^{55}$ study revealed that $63 \%$ of successful placement of learners with special needs in schools depend on comprehensive multidisciplinary assessment. However, it is ironical that at the minimum 11 to six learners with special needs are yet to be assessed and placed in special and integrated schools; notwithstanding, that there are no statistics provided for regular schools. EARC 4 admitted.

In very rare cases or not at all do head teachers send learners to resource centres or EARC centres for assessment and placement in special units or special schools. It is us who make arrangements to visit schools, mostly integrated and special schools. Some head

\footnotetext{
${ }^{53}$ Hayes, A.M. and Bulat.(2018)

54 KISE.(2018)

${ }^{55}$ Malasi Nyali Maghuwa Flora; Samuel Wanyonyi Juma, 'The Role of Educational Assessment Resource
}

teachers are co-operative, others are not cooperative.

Therefore, it is incumbent upon head teachers to formulate well-structured collaborative partnership participation including teachers, parents and experts in assessment and placement of learners in their schools. QASO 5 concurred:

In a way head teachers collaborate with EARC officers who visit schools to assess learners for referrals to special schools or units and also physiotherapy. EARC officers have specialized skills to identify and assess learners but we (QASOs) do not have. EARC officers can also train teachers if invited, though they are few.

The findings in Figure 1 on referral of learners for physiotherapy and expertize counselling reveal that average score of $42.3 \%$ for head teachers, and lower score of $29.6 \%$ for teachers consented to it. On the other hand, quite high negative scores of $57.7 \%$ for head teachers and very high scores of $70.4 \%$ for teachers contended against it. These findings show converging views from the respondents that very few learners were referred for specialized services by head teachers, with very little or without the knowledge of the teachers in school. This implies that assessments and referrals of learners were not well-structured, documented and followed-up.

The findings of document analysis in Table 1 on referral records for learners in the sampled schools show that only $35.2 \%$ of schools kept referral and assessment records for learners with special needs. Majority of the schools represented by $64.8 \%$ did not keep the records. This implies that majority of the schools did not keep up to date referral records or

Centres in Promoting Inclusive Education in Kenya', International Journal of Science and Research (IJSR), 7.1 (2018), 885-89 < https://doi.org/10.21275/ART20179263>. 
documents that ought to be used collaboratively by the school administration, teachers, parents and support service providers in monitoring the assessment, placement, special needs and medical conditions of learners in schools. These findings are supported by Irungu ${ }^{56}$ study which indicated that only $14.4 \%$ of respondents cited the role of EARCs in making referrals to regular, integrated and special schools. According to Republic of $\mathrm{Kenya}^{57}$, nationally, there are only eight EARC county workshops, which are inadequate to provide services for learners with special needs.

The findings on referral of learners are adduced to Juma and Malasi ${ }^{58}$ study that indicate that less than half of referral and assessment centres in Kenya involve audiologists, speech therapists and nutritionists, but vision therapists and regular teachers are rarely involved in the referral and assessment. It is revealed that $76 \%$ of referral centres use obsolete equipment, a situation that has culminated in $72 \%$ of regular schools admitting learners with special needs without proper assessment and treatment. According to Talley and Brintnell ${ }^{59}$, admitting these learners without an expert referral is an act of education exclusion.

Schools collaborate with health care workers in screening learners for possible health conditions, referral for medical help and enrolment. For instance, congenital disabilities such as down syndrome can be prevented through early intervention before and when enrolled in school to enable them hear and communicate verbally. ${ }^{60}$ It was prudent that head teachers initiate collaborative structures

\footnotetext{
56 Irungu.(2014)

${ }^{57}$ Republic of Kenya. (2018a).

58 Juma and Malasi. (2018)

${ }^{59}$ Lauren Talley and E. Sharon Brintnell, 'Scoping
} the Barriers to Implementing Policies for Inclusive Education in Rwanda: An Occupational Therapy Opportunity', International Journal of Inclusive Education, with teachers, parents, referral and assessment centres, and service providers to provide physiotherapy, expertize counselling and other support services for learners with special needs.

The findings on outsourcing of funds for infrastructural provisions for learners with special needs from Figure 1 showed that this item elicited lower positive scores of 31\% and $30.3 \%$ from head teachers and teachers; however, the same respondents registered higher negative scores accounting for $69 \%$ and $69.7 \%$ respectively. The findings of document analysis on outsourcing of funds in Table 1 revealed that only $26.8 \%$ of the schools had up to date records showing allocation of funds to the school. A higher negative score of $73.2 \%$ of the schools did not have up to date records on the same. These findings suggest that majority of schools failed to initiate collaboration with partnerships to outsource additional funds. The few schools that received some funds, did not have proper documentation. QASO 6 was embarrassed to explain:

Due to lack of reliable statistics for special learners, some schools inflate numbers. A case of a head teacher picking learners from regular classes to get additional funding. Learners who've transferred are still in enrolment and schools continue getting funds from donors. I personally, I have not seen any record on the money received from donors by the head teachers. They keep it as a secret.

The ramification of the findings in Figure 1 on outsourcing of funds is that majority of

20.4

(2016), 364-82 <https://doi.org/10.1080/13603116.2015.1081634>.

${ }^{60} \mathrm{H}$ Mariga, L., McConkey, R. \& Myezwa, Inclusive Education in Low-Income Countries: A Resource Book for Teacher-Educators, Parents, Trainers and Community Development Workers (Cape Town: Atlas Alliance and Disability Innovations Africa, 2014). 
the schools had very minimal funding channels for infrastructure development; thus, failure to improving on infrastructure. In addition, the outsourced funds were not fully accounted for in terms of channelling it for the intended purpose, and auditing how it was spent. The findings on outsourcing of funds are in semblance to Irungu ${ }^{61}$ study that show majority, $87.5 \%$ of respondents cited insufficient funding streams and levels as a challenge facing head teachers, with the majority of them, $97.6 \%$, asking for additional funds.

The government funding in 2017/2018 was KShs. $1,420 /=$ capitation per learner with special needs and KShs. 2,300/= for teaching and learning materials, which is too far inadequate. ${ }^{62}$ Thus, there was need for head teachers to initiate collaborative partnerships to outsource additional funds for infrastructure development and improvement. Lack of coordination among partnerships hinders the infrastructural provisions for learners with special needs. For instance, a number of schools receive funds from multiple sources such as government, parents, donors and well -wishers as well as funds for EARC operations channelled through Constituency Development Fund; thus, posing accountability challenges. ${ }^{63},{ }^{64}$ In addition, there is inaccurate data to inform on computation and allocation of resources to learners. ${ }^{65}$

DiPaola and Walther-Thomas ${ }^{66}$ opine that head teachers, teachers and local education officers conduct periodic needs assessments to identify areas for school improvement, and coordinate budgets to ensure that education

${ }^{61}$ Irungu.(2014).

${ }^{62}$ Republic of Kenya. (2018a).

${ }^{63}$ Republic of Kenya.(2016).

${ }^{64}$ Republic of Kenya. (2018a).

${ }^{65}$ Republic of Kenya. (2018a).

66 C. DiPaola, M. F., and Walther-Thomas, Principals and Special Education:The Critical Role of School Leaders (Florida, 2003).

${ }^{67}$ Education. needs for diverse learners are addressed in schools. National Council for Special Education $^{67}$ postulate that school's collaboration with partnerships enable it to acquire adequate funding, resources and support services for effective implementation of inclusive education.

The findings on sponsorship to support school programmes such as open day and outreach for diverse learners from Figure 1 showed that $39.4 \%$ and $24.2 \%$ of head teachers and teachers consented to it. However, a bigger proportion of the same respondents accounting for $60.6 \%$ and $75.8 \%$ were contended. This implies that teachers were less aware of the sponsorship for open day and outreach programmes partly because there was no well-structured collaborative initiative for partnership participation in schools. In seconding these findings, Irungu ${ }^{68}$ study found out that only $20.8 \%$ of the study participants indicated that EARCs were involved in organizing awareness programmes on the education of learners with special needs. The implication was that teachers, parents and other stakeholders were left out of the uncoordinated sponsorship initiative which resulted into very minimal participation and outcomes in the majority of schools.

Janney, Snell, Beers, and Raynes ${ }^{69}$ argue that head teachers need to work with education officials in their localities and other stakeholders to ensure that learners with special needs have access to buses, buildings, classrooms and extracurricular activities. Sanders and Harvey ${ }^{70}$ opine that community partners provide funds for school activities

68 Irungu. (2014).

${ }^{69}$ M. Janney, R., Snell, M. E., Beers, M. K., \& Raynes, 'Integrating Students with Moderate and Severe Disabilities into General Education Classes.', Exceptional Children, 61.5 (1995), 425-439.

70 A Sanders, M. G. and Harvey, 'Beyond the School Walls: A Case Study of Principal Leadership for School- Community Collaboration.', Teachers College Record, 104.7 (2002), 1345-1368. 
including transport and fees for the learners. Some communities in Kenya, NGOs and CBOs assisted in payment of school fees, provided assistive devices and general care of learners with special needs, and hired aides at a cost of KShs. 5000 per parent; thus enabling school enrolment and attendance ${ }^{71}$. Therefore, it was evident that collaborative partnerships were unutilized opportunities that head teachers needed to have fully exploited to effectively implement inclusive education in schools.

\section{Effectiveness of head teachers' collaborative partnerships for implementing inclusive education}

The findings in Figure 2 suggest that majority of the respondents were dissatisfied with the low level of participation of partnerships in the provision of support services in their schools; thus, impeding on inclusive education implementation. EARC 4 observed:

In sporadic cases or not all do schools collaborate with stakeholders or partners. Some

NGOs visit schools when they have an interest, but lack of coordination limits collaboration. Some well-established schools have a number of their programs sponsored by donors, in areas such as textbooks, assistive devices, hiring aides, and infrastructure.

Further analysis of the findings on the effect of collaboration of partnerships in provision of specialized teaching and learning materials from Figure 2 indicated that only $12.7 \%$ and $26.9 \%$ of head teachers and teachers were contented with the participation of partners on this initiative. Contrastingly, $62 \%$ and $62.6 \%$ of the same respondents were contended with the low participation of

${ }^{71}$ Republic of Kenya. (2014b).

72 National Association of School Psychologists, 'Position Statement on Home-School Collaboration: Establishing Partnership to Enhance Educational Outcomes', 2005. partners on the initiative. This implies that there was low partnership participation on this program; thus, effecting on low access and participation of diverse learners in learning.

According to the National Association of Schools Psychologists ${ }^{72}$, well-coordinated collaborative partnerships in schools are significant for learners, teachers and the families in terms of higher academic achievements, improved behaviour, higher participation in school programmes, improved school attendance with fewer referrals to special education. For instance, partnerships between Syracuse University's School of Education from USA, Kenyatta University and Thika School of the Blind saw to it that learners were assessed, trained on the use of assistive technology such as Ipads and keyboards; as a result, learners were able to access learning materials without the assistance of readers. ${ }^{73}$

The findings on the effect of collaboration of partnerships in assessment of learners with special needs in Figure 2 revealed that lower scores of $15.4 \%$ and $30.6 \%$ of head teachers and teachers felt that at least there was participation of partners in the assessment. However, majority, $63.4 \%$ and $60.3 \%$ of the same respondents strongly felt that the participation was low. This suggests that only few integrated and special schools represented by $15.4 \%$ and $30.6 \%$ had their learners assessed and placed in their schools through some partnership collaborative efforts. However, majority of the schools, particularly regular schools failed to initiate and coordinate collaborative partnerships to assess and place learners with special needs in their schools. The implication of these findings is that there was very low and uncoordinated participation of

${ }^{73}$ United Nations Department of Economic and Social Affairs, Global Status Report on Disability and Development (New York, 2015). 
partnership in assessment and placement of learners with special needs in majority of the schools; hence, denying them access and participation in learning.

In Lesotho coordinated collaborative partnership between schools, NGOs and CBOs resulted in successful implementation of inclusive education with $75 \%$ of diverse learners between ages 5-15 years assessed and placed. ${ }^{74}$ In addition, Villa et al. $^{75}$ study on school-community partnerships in Vietnam, saw to it that teachers were trained to cooperative learning, assessment and placement of learners with special needs in regular classrooms. The effect of these collaborative initiatives was that the access and participation in learning of learners with special needs increased from $30 \%$ to $86 \%$.

The findings on outsourcing of funds for infrastructural provisions and sponsoring school programs from Figure 2 showed that lower positive scores of $14.1 \%$ and $27.6 \%$ of head teachers and teachers felt that there was little participation on this initiative. Ironically, higher negative scores of $66.2 \%$ and $60.9 \%$ of the same respondents strongly felt that there was very low participation of partners on this initiative. These findings are suggestive that majority of the head teachers lacked common understanding with teachers and other stakeholders on the initiative to outsource funds for their schools. The implication is that majority of the stakeholders and partners lowly participated not only on the initiative of outsourcing funds for the schools programs but were also discouraged from participating in providing support services and educational needs of diverse learners in the schools. This is partly attributed to personal initiatives by head teachers and school committees to outsource

${ }^{74}$ Mariga, L., McConkey, R. \& Myezwa. (2014).

75 and J. S. Thousand Villa, R. A., P. M. Van Le Tac, S. Muc, N. T. M. Ryan, C. Weill Thuy, 'Inclusion in Vietnam: More than a Decade of Implementation', funds for their schools programs of interest to themselves, without proper coordination with other stakeholders including teachers, parents, sponsors, and partnerships. EARC officer 6 submitted.

They rarely speak about donors or money they get from them. As a matter of concern they divert money for inclusive education and even the one meant for infrastructure to other areas of the school. There are no records to show how much funding they received from sponsors for learners with special needs in special units in regular primary schools.

The revelation by EARC officer 6 point to financial impropriety in schools that need immediate remedy from internal and external monitoring systems in order to secure and rechannel funds meant for inclusive education. In support to these findings, Buhere and Ochieng $^{76}$ findings indicate that even though $53 \%$ (16) of head teachers were satisfied with improved government funding for school infrastructure, special teachers felt that increased funding was essential and that mechanism be put in place to avoid diversion of funds meant for learners with special needs to other areas. It was revealed that $62.5 \%$ of the teachers were dissatisfied with infrastructure including toilets which were not appropriate because they were not modified due to lack of consultation with technical experts. QASO 5 confirmed.

They get some financial support to improve on infrastructure but they rarely speak about it. Most schools rely on government funding for infrastructure and instructional materials, but it is still too small to use it on

Research and Practice for Persons with Severe Disabilities, 28.1 (2003), 23-32.

${ }^{76}$ Buhere and Ochieng. (2013) 
infrastructure, special equipment, cater for special diet and services.

Deng and Holdsworth ${ }^{77}$ study found out that head teachers coordinated with parents, special teachers and service providers and had them participate in school programmes such gathering and maintaining data on learners with special needs, formulating school policy and school development or infrastructure plans, and sponsoring training in specialized and instructional skills to handle the learners. The effect was that the enrolment of learners with special needs increased from 30\% to $60 \%$. Therefore, it was incumbent upon the head teachers to coordinate collaborative partnerships in identified school programs in order to participate in providing educational resources and support services for implementing inclusive education.

\section{Association between head teachers' collaborative partnerships with implementation of inclusive education}

The null hypothesis tested was:' there is no significant difference between head teachers' collaborative partnerships with implementation of inclusive education.' The independent variable was factored in head teachers' collaborative partnerships; while the dependent variable was indicated in participation rates. The tests are presented in chi-square statistical Table 2.

Table 2. Chi- square results*specialized teaching/learning materials vis-à-vis participation for learners with special needs Chi-square test

\begin{tabular}{lrcc}
\multicolumn{1}{c}{ Value } & df & & Asymp.sig \\
\hline $\begin{array}{l}\text { Pearson Chi- } \\
\text { square }\end{array}$ & $4.722^{\mathrm{a}}$ & 4 & .317 \\
$\begin{array}{l}\text { Likelihood Ratio } \\
\text { Linear-by-linear }\end{array}$ & 5.296 & 4 & .258 \\
$\begin{array}{l}\text { Association } \\
\text { N of valid cases }\end{array}$ & .761 & 1 & .383 \\
& 71 & & \\
\hline
\end{tabular}

77 M. and J.C. Holdsworth Deng, 'From Unconscious to Conscious Inclusion: Meeting Special a. 7 cells $(70.0 \%)$ have expected count less than 5. The minimum expected count is .72.

\section{Conclusion}

The study established that majority of schools had weak, uncoordinated and unstructured collaborative partnership that yielded low level of partnership participation in the provision of support services in their schools; consequently, hindering access and participation of diverse learners in education. This was attributed to head teachers' self-willed initiatives and lack of partnership networking skills for their schools. The chi-square analysis confirmed that there was statistically significant association between head teachers' collaborative partnerships with the implementation of inclusive education.

\section{Recommendations}

The Board of Management, School Committee and head teachers should broaden their partnerships engagements. First, they should increase their capacity through expertize training in partnership collaboration, formulate institutional strategic plans for inclusive education, and network or benchmark with likeminded institutions to gain experience with partnerships for inclusive education.

A well-structured coordinated framework for partnerships engagement and participation should be redesigned from the national level cascading to the schools with focus on inclusive education. The programs of partnerships such as provision of specialized teaching and learning materials, assessment of learners, and outsourcing of funds amongst others should serve as impetus for deliberate consultative planning for provision of educational needs and support services for inclusive education implementation.

Education Needs in West China.', Disability and Society, 22.5 (2007), 507-522. 


\section{Reference}

\section{Book}

Baker, T.I, Doing Social Research, 2nd edn (New York: McGraw, 1994)

Best, J. W., \& Kahn, J. V., Research in Education, 10th edn (Upper Saddle River, NJ: Pearson Education, Inc., 2006)

Creswell, J.W, Educational Research: Planning, Conducting and Evaluating Quantitative and Qualitative Research, 4th edn (London: Pearson Research, 2012)

CRPD, Convention on the Rights of Persons with Disabilities (New York, 2006)

KISE, The National Survey on Children with Disabilities and Special Needs (Nairobi, 2018)

Cronbach, L.R., Essentials of Psychological Testing, 3rd edn (New York: Harper and Row, 1970)

Nairobi City County, Taskforce Education Report. (Nairobi, 2015)

\section{Journal}

Adoyo, O.P. \& Odeny, L.M., 'Emergent Inclusive Education in Kenya: Challenges and Suggestions', . International Journal of Research in Humanities and Social Studies, 2.6 (2015), 47-52

Gathumbi, Agnes, Henry Ayot, John Kimemia, and Samson Ondigi, 'Teachers' and School Administrators' Preparedness in Handling Students with Special Needs In Inclusive Education In Kenya', Journal of Education and Practice, 6.24 (2015), 129-39

Talley, Lauren, and E. Sharon Brintnell, 'Scoping the Barriers to Implementing Policies for Inclusive Education in Rwanda: An Occupational Therapy Opportunity', International Journal of Inclusive Education, 20.4 (2016), 364-82

Juma, Malasi Nyali Maghuwa Flora; Samuel Wanyonyi, 'The Role of Educational Assessment Resource Centres in Promoting Inclusive Education in Kenya', International Journal of Science and Research (IJSR), 7.1 (2018), 885-89 $<$ https://doi.org/10.21275/ART20179 $263>$
WHO, CBR Guidelines. Health Component (Geneva, 2010)

- World Report on Disability 2011', American Journal of Physical Medicine Rebabilitation Association of Academic Physiatrists, 9.1 (2011), 549

Billingham, Sophie Am, Amy L. Whitehead, and Steven A. Julious, 'An Audit of Sample Sizes for Pilot and Feasibility Trials Being Undertaken in the United Kingdom Registered in the United Kingdom Clinical Research Network Database', BMC Medical Research Methodology, $13.1 \quad$ (2013), 1 $<$ https://doi.org/10.1186/1471-228813-104>

Stoner, J. B., Bock, S. J., Thompson, J. R., Angell, M. E., Heyl, B. S., \& Crowley, E. P., Welcome to Our World: Parent Perceptions of Interactions between Parents of Young Children with ASD and Education Professionals', Focus on Autism and Other Developmental Disabilities, $20.1 \quad$ (2005), 39-51 $<$ https://doi.org/10.1080/13603116.20 15.1081634>

Meenakshi, S., Anke de Boer, and Sip, J.P, 'Inclusive Education in Developing Countries: A Closer Look at Its Implementation in the Last 10 Years.' (Umang, Jaipur India: Routeledge.TaylorandFrancisGroup., 2013)

\section{Online Reference}

Barton, Paul E, 'Parsing the Achievemnt Gap: Baselines for Tracking Progress', Policy Information Report, Educational Testing Service, Policy Information Center, 2003, 1-42

Borg, J, The State of the World's Children 2013 Children with Disabilities. (New York, 2013)

Buhere, Pamela, and Pamela Ochieng, 'Usage of Selected Resources for Inclusive Education in Mainstream Primary Schools: Issues and Challenges From a Kenyan Perspective.', Problems of Management in the 21st Century, 8 (2013), $16-24$

Deng, M. and J.C. Holdsworth, 'From Unconscious to Conscious Inclusion: Meeting Special Education Needs in 
West China.', Disability and Society, 22.5 (2007), 507-522.

Department for International Development, Accessing Inclusive Education for Children with Disabilities in Kenya:Global Campaign for Education. (United Kingdom, 2015)

DiPaola, M. F., and Walther-Thomas, C., Principals and Special Education:The Critical Role of School Leaders (Florida, 2003)

Duhaney, L. G. M. and Spencer, J. S, 'Parental Perceptions of Inclusive Educational Placements', Remedial and Special Education, 21.2 (2000), 121-29.

Education, National Council for Special, Literature Review of the Principles and Practices Relating to Inclusive Education for Children with Special Needs. (Europe, 2010)

Epstein, J. L, School, Family and Community Partnerships: Preparing Educators and Improving Schools. (Westview: Boulder, CO, 2001)

Gold, B, Social Construction of Urban Education: New Jersey Whole School Reform and Teachers' Understanding of Social Class and Race (New York: Pace University, 2002)

Government of India, Scheme of Assistance of Assistance to Disabled Persons for Purchase/Fitting of Aids/ Appliances (ADIP Scheme) (New Delhi, 2014)

Handicap International, Inclusive Education in Kenya Assessment Report. Policy Paper on Inclusive Education in Kibera and Dandora. (Nairobi, 2013)

Hayes, A.M. and Bulat, J, Disabilities Inclusive Education Systems and Policies Guide for Low and Middle Income Countries. (New York: RTI Press Publication, 2017)

Irungu, J.M., 'Influence of Head Teacher Leadership Development on Implementation of Inclusive Education in Public Primary Schools in Kiambu County, Kenya' (University of Nairobi, 2014)

Janney, R., Snell, M. E., Beers, M. K., \& Raynes, M., 'Integrating Students with Moderate and Severe Disabilities into General Education Classes.', Exceptional Children, 61.5 (1995), 425-439.

Kovač Cerović, T., Pavlović Babić, D., Jovanović, O., 'Foundations for Development of Monitoring Framework for Inclusive Education in Serbia.', in
Monitoring Framework for Inclusive Education in Serbia, ed. by I. (Ed.) In Latinović (Belgrade: Unicef, Serbia, 2014), pp. 1241)

Layton, N., 'Problems, Policies and Politics: Making the Case for Better Assistive Technology Provision in Australia.', Disability and Rebabilitation Assistive Technology, 10.3 (2015), 240-44

Leithwood, K., Seashore, K.L., Anderson, S. and Wahlstrom, K., Review of Research How Leadership Influences Student Learning (University of Minnesota: Wallace Foundation, 2014)

Mariga, L., McConkey, R. \& Myezwa, H, Inclusive Education in Low-Income Countries: A Resource Book for Teacher-Educators, Parents, Trainers and Community Development Workers (Cape Town: Atlas Alliance and Disability Innovations Africa, 2014)

Njoka, E., Riechi, A., Obiero, C., Kemunto, E., Muraya, D., Ongoto, J. \& Amenya, D., Towards Inclusive and Equitable Basic Education System: Kenya's Experience (Ouagadougou, Burkina Faso, 2013)

Psychologists, National Association of School, 'Position Statement on Home-School Collaboration: Establishing Partnership to Enhance Educational Outcomes', 2005

Republic of Kenya. (2014a), National Education Sector Plan 2013-2018. (Nairobi, 2014)

Republic of Kenya. (2014b)., National Special Needs Education Survey Report. (Nairobi, 2014)

Republic of Kenya. (2018a), Sector Policy for Learners and Trainees with Disabilities (Nairobi, 2018)

Republic of Kenya. (2018b), Sessional Paper on Reforming Education and Training for Sustainable Development (Nairobi, 2018)

Republic of Kenya, Education Sector Report 2017/18-2019/20. (Nairobi, 2016)

Sanders, M. G. and Harvey, A, Beyond the School Walls: A Case Study of Principal Leadership for School- Community Collaboration.', Teachers College Record, 104.7 (2002), 1345-1368.

UNESCO, Education for All National Review Report: Kenya (Paris, 2015)

- Policy Guidelines on Inclusion in 
Education. (Paris, 2009)

United Nations Department of Economic and

Social Affairs, Global Status Report on Disability and Development (New York, 2015)
Villa, R. A., P. M. Van Le Tac, S. Muc, N. T. M. Ryan, C. Weill Thuy, and J. S. Thousand, 'Inclusion in Vietnam: More than a Decade of Implementation', Research and Practice for Persons with Severe Disabilities, 28.1 (2003), 23-32 